\title{
Research in the Mathematical Sciences: a new open access journal
}

Ken Ono

Correspondence:

ono@mathcs.emory.edu

Department of Mathematics and

Computer Science, Emory

University, Atlanta, Georgia 30322, USA

\section{Editorial}

Research in the Mathematical Sciences is an exciting new journal presented by SpringerOpen. This journal provides open access publication of the highest level research in the mathematical sciences. The standards are set by a distinguished editorial board whose expertise spans applied mathematics, theoretical mathematics, and theoretical computer science.

I will serve as the journal's first Managing Editor-in-Chief, and I am excited to work with three outstanding Editors-in-Chief: Bjorn Engquist, Olga Holtz, and Yuri Tschinkel.

Open access publishing is not without costs. Research in the Mathematical Sciences therefore levies an article-processing charge. We routinely waive charges for authors from low-income countries, and for the first 2 years, charges will be waived for authors who are not affiliated with a SpringerOpen Member institution and who do not have suitable funding earmarked for such charges. As a guiding principle, all editorial decisions will be based solely on the scholarship and appropriateness of an article.

Therefore, article-processing charge waivers are also available at the editors' discretion.

We invite you to submit your articles.

Ken Ono

Managing Editor-in-Chief

Received: 16 April 2014 Accepted: 16 April 2014

Published: 17 June 2014

doi:10.1186/2197-9847-1-1

Cite this article as: Ono: Research in the Mathematical Sciences: a new open access journal. Research in the

Mathematical Sciences 2014 1:1.
Submit your manuscript to a SpringerOpen ${ }^{\circ}$ journal and benefit from:

- Convenient online submission

Rigorous peer review

- Immediate publication on acceptance

- Open access: articles freely available online

- High visibility within the field

- Retaining the copyright to your article

Submit your next manuscript at springeropen.com 